\title{
Ebeveynlerin çocukları için Montessori yöntemi uygulayan anaokulu seçme nedenleri
}

\section{Parent's reasons choosing Montessori school for their child}

\section{Makale Geçmişi \\ Geliş : 17 Şubat 2020 \\ Düzeltme : 18 Ocak 2021 \\ Kabul : 9 S Subat 2021}

\section{Makale Türü}

Araştırma Makalesi
Article History

Received : 17 February 2020

Revised : 18 January 2021

Accepted : 9 February 2021

Article Type

Research Article

\section{Aylin Sop ${ }^{1}$, Müşerref Dalkıran Turgut ${ }^{2}$}

Öz: Montessori yöntem ve uygulamaları, çocukları Montessori okuluna devam eden ebeveynler için anlaması bazen zor ve karmaşık gelebilir. Ayrıca ebeveynlerin neden çocuklarını Montessori yöntemi uygulayan okullara gönderdikleri konusu halen belirsizdir. Bu nedenle bu araştırma ile ebeveynlerin Montessori okulunu tercih etme sebeplerinin belirlenmesi amaçlanmıştır. Konya ilinde Montessori yöntemi uygulayan bir okula kayıtlı olan 4-6 yaş çocukların ebeveynleri ile yürütülen bu çalışmada 30 ebeveyn ile yarı yapılandırılmış görüşme tekniği ile görüşülmüştür. Araştırma sonuçları ebeveynlerin çocuğa özgür bir ortam sağlanması, birebir eğitim verilmesi, materyal çeşitliliği, çocuğa özgüven ve sorumluluk kazandırması yönünden Montessori okulunu tercih ettiklerini göstermektedir. Ayrıca çocuklara kendine güvenen birey, özgür ruhlu, mutlu ve kendi kararlarını verebilen bireyler olmasını teşvik ettiklerini düşünmektedirler. Ebeveynlerin Montessori eğitim felsefesinin bireysel eğitim, özgür ortam, materyal ve sınıf ortamı gibi belirli özelliklerini daha çok önemsedikleri görülmüştür.

Anahtar Kelimeler: Montessori Yöntemi, Okul Tercihi, Ebeveyn, Erken Çocukluk Eğitimi.

Abstract: Montessori Method and its practices can sometimes seem difficult and complex to understand, even for parents whose children are attending a Montessori school. It is also unclear why parents send their 4-6 years old children to schools that implement the Montessori Method. For this reason, the current study aimed to determine the reasons for parents to choose a Montessori school. In this study, which was carried out with the parents of children enrolled in a school that implements the Montessori Method in Konya, 30 parents were interviewed with the semi-structured interview technique. The results of the research show that parents prefer the Montessori school as it provides a free environment, allows one to one education, offers a great variety of materials and enhances selfconfidence and sense of responsibility in children. They also think that the school encourages children to be self-confident, free-spirited and happy and to make their own decisions. It has been observed that parents care more to certain features of Montessori education philosophy such as individual education, free ambient, material and classroom environment.

Keywords: Montessori Method, School Choice, Parent, Early Childhood Education. 


\section{SUMMARY}

\section{Introduction}

Today, increasing efforts are made to provide an eclectic curriculum models created by the synthesis of different educational approaches to train qualified individuals, to handle individual differences, to enable students to relate what they have learned to real life and to provide education in natural conditions under the influence of emerging technological and scientific developments (Ulutaş \& Tutkun, 2015). These eclectic educational approaches have emerged under the influence of many thinkers and theorists. The perspectives of thinkers and theorists such as Piaget, Frobel, Dewey, Montessori, Rousseau, which center on children, care about individual differences and advocate a democratic learning environment, have brought the education models of Bank Street, Dalton Lab, Waldorf, Reggio Emilia and Montessori to the fore.

One of the educational methods that respect the child and cares about the child's own dynamics is the Montessori Method. The Montessori Method was named after Dr. Maria Montessori, who devoted herself to the education of children. Maria Montessori based the formation process of the new education on the reorganization of the existing education and its harmony with nature which is directly within life. The basic principle of this education is the relationship of the child with nature, his/her personal development and occurrence of this development freely. The Montessori Method aims to maximize all the developmental stages and features of the child as an individual. It allows the child to grow up as an individual who fosters the sense of curiosity, constantly asks questions and can find answers. The important thing is to let the person see that he / she has become self-sufficient (Keskin, 2017). For this reason, the orientation towards educational approaches that support all developmental stages of preschoolers and that attempt to create self-sufficient individuals is very high. Montessori schools are one of them, but they also support the physical, social-emotional and cognitive development of the child in a free environment within natural conditions. It emphasizes that information should be learned by children by discovering and experiencing rather than through direct conveyance of it. It also requires igniting the child's creativity, entrepreneurship and self-esteem, giving importance to the child's freedom and respecting the child.

Parents are one of the most important participants of Montessori schools. It is very important to involve parents in the school environment to support the child's developmental areas. Parents are able to help to develop home-school relationships by means of parent-training workshops built on the principles of the philosophy of Montessori education. Parents' role in the home environment is very important to ensure that children are more experienced and consistent in applications performed in the Montessori classroom environment (Walls, 2018). The reason behind parents' preference for Montessori schools for their children is that they adopt practice-based learning approach, offer individualized teaching and foster child characteristics conducive to the personal development of the child (Parker, 2007).

\section{Method}

The current study employed a basic qualitative research method to determine parents' reasons for selecting a Montessori school. The study was conducted with the participation of parents whose children are enrolled 
in a Montessori school in the city of Konya. It was attempted to reach the parents of 50 children attending the Montessori school but only 30 of them responded and accepted to participate in the study. As the data collection tools, a personal information form and a semi-structured interview form developed by the researcher were used in the current study. The data of the study were collected with the semi-structured interview technique. The data collected with the interview form were analyzed by using content analysis. In order to improve the validity in the study, opinions of the field experts were sought while developing the interview form. Moreover, direct quotations were made from the participations in the findings section. While presenting the direct quotations from the parents, their identities were kept confidential and codes names were used instead. In order to increase the reliability of the study, two researchers coded the data separately in the data analysis process and then they came together to review similarities and differences between their codes and themes and efforts were made to agree on differences.

\section{Results}

The parents' reasons for preferring a Montessori school can be presented in order of importance as follows: the school environment is a free environment, there is one-to-one training, concrete concepts are learned, there is a great variety of materials, the school environment is related to real life and students' self-confidence is fostered. The parents' opinions about the philosophy of Montessori education in terms of the perspective of child outcomes are subsumed under the following headings: supporting all the areas of development, academic achievement and learning to take responsibility; in terms of educational approach, they can be subsumed under the following headings: individualized education, child-centered education, daily life skills and free education. The parents stated that "implementation of one-to-one training, "presence of an environment that supports development", "provision of easy movement/free spaces" and "simple and natural classroom colors" are more effective in supporting the development of their children as it allows children to act freely and gives one-to-one training to children.

Considering the parents' views on the Montessori school classroom materials; "Educative and instructive", "teaching with fun" are among the main views. When the opinions of the parents about the teachers of the Montessori school are examined; They stated that they are "interested / successful", "loving their job / smiling face", "equipped / conscious and different" and "paying attention to individual differences". The parents' opinions about the possible gains to be achieved by their children in the Montessori school can be summarized as follows; "self-confident individual", "free-spirited/happy" "making his/her own decisions", "supporting the areas of development", "acquiring daily life skills" and "developing according to their age". Finally, the parents were asked their expectations of the Montessori school and whether their expectations were met or not. When their responses were analyzed, it was found that 12 of the parents stated "yes, they welcomed it as I expected", 10 of them "definitely welcomed", 6 of them "I met better than I expected", 1 of them "the school is not over yet" and 1 of them "did not answer". It was also found that the parents expect the school, "to make their children happy", "support all development areas", "meet parental satisfaction", "maintain the same determination in education", and "be the guide of the school". 


\section{Conclusion and Discussion}

When the literature is examined, it is seen that the reasons for parents to prefer one education model have not been examined sufficiently so far. The current study is believed to reveal some ideas that will help fill a void in the literature. The study shows that parents prefer Montessori schools for a limited number of reasons. They emphasized few features of Montessori schools that make them different from other schools. The reasons such as individualized (one-on-one) education, free environment, material diversity and the suitability of the classroom environment for children were emphasized more. When the parents were asked why they preferred a Montessori school for their children, more than half of them stated as children are provided with free environment, individual education is given and sense of self-confidence is fostered. Moreover, one in every four parents stated that materials used are from real life, there is a great variety of materials and materials are suitable for children. Parents regard the education of their children in Montessori schools as an extension of their upbringing. Due to their interest in the principles of the philosophy of Montessori education, they are taking advantage of any opportunity to learn about Montessori education. They emphasize that school life is not supported by traditional education, but by natural life. They try to make sense of the philosophy of Montessori education and see the difference between memorizing and experiencing (Kahn, 1990). The primary characteristics aimed to be imparted to children by the Montessori education approach are similar to the opinions of the parents expressed in the current study. In this regard, the primary characteristics seem to be necessary to be imparted to children by both parents and Montessori education approach include being self-sufficient, being able to live in harmony with the environment and being able to make their own decisions.

According to the research results, further research is considered important in order for parents to understand the principles of Montessori education and to gain awareness. It is not possible to limit the Montessori education as an educational process only for the child. Parents' knowledge on this subject and their contribution to the process are an important part of this education. For this reason, studies can be conducted with larger samples, which received opinions from parents of children who previously attended Montessori schools. 


\section{GİRIŞ}

Her toplumda ebeveynlerin çocukları için eğitimden beklentileri olmaktadır. Çocukların gelişimsel açıdan sağlıklı bir şekilde büyümesi, topluma yararlı, kendine yetebilen, sorumluluklarını bilen birer yetişkin olması ve var olan potansiyeli en üst boyutlara taşıması, çocuklara çok erken yaşta sağlanan olanaklar doğrultusunda gerçekleşmektedir (Keskin, 2017). Çocuğun bilişsel, sosyal, duygusal, fiziksel ve dil gelişim alanlarının çok hızlı bir şekilde gelişip değiştiği, çeşitli yeteneklerin kazanıldığı ve öğrenmenin son hızla devam ettiği erken yaşlarda bireyin içinde bulunduğu çevresel faktörlerin etkisi yadsınamayacak derecede fazladır (İnan, 2012). Ailenin desteği ile birlikte birincil çevreden olan okul öncesi eğitim kurumları sayesinde olumlu bir çevre oluşturmak çocuğun beceri ve yeteneklerinin şekillenmesinde etkili olmaktadır (Heckman, 2011). Okul öncesi eğitimin başlıca hedefleri arasında yüksek kaliteli olması, gelişimsel olarak uygun olması ve çocuğun kapsamlı bir şekilde gelişim alanlarını desteklenmesi yer almaktadır (Zigler, Gilliam ve Jones, 2006). Her bir çocuğu önemsemek ve her bir çocuğun ilgi, merak ve yetenekleri doğrultusunda eğitim ortamı hazırlamak, çocukların kendi istekleri ile sürece aktif katılımı sağlayarak öğrenmelerinin daha kalıcı olmasına yardımcı olacağı düşünülmektedir.

Günümüzde teknoloji ve bilimsel gelişmelerin etkisiyle gelişen eğitim sistemini nitelikli bireyler yetiştirmenin yanı sıra çocukların bireysel farklılıklarına yönelik öğrenme süreçleri oluşturma, yaşamla ilişkilendirme, eğitimin doğal koşullar ile gerçekleşmesini sağlama ve farklı eğitim yaklaşımlarının sentezinden oluşan eklektik program modelleri sağlama çabaları artmaktadır (Ulutaş ve Tutkun, 2015). Bu eklektik eğitim yaklaşımları birçok düşünür ve kuramcının erken dönem gelişim ve eğitim ile ilgili araştırmalarından etkilenerek ortaya çıkmışır. Piaget, Frobel, Dewey, Montessori, Rousseau gibi düşünür ve kuramcıların çocukları merkeze alan, bireysel farklılıkları gözeten, demokratik bir öğrenme ortamını savunan bakış açıları, Waldorf, Reggio Emilia ve Montessori gibi eğitim modellerinin daha çok ön plana çıkmasına ve yüksek kalitede erken çocukluk eğitim programlarına yönelik talebin artmasına sebep olmuştur (Schweinhart, 2017).

Erken çocukluk eğitim modellerinden Montessori yöntemi yüzyılı aşkın süredir diğer ülkelerde ve son yıllarda da ülkemizde çok rağbet gören ve uygulanan bir yöntemdir. Çocuğa saygı duyan ve çocuğun kendi dinamiklerini önemseyen eğitim yöntemlerinden olan Montessori yöntemi adını kendisini çocukların eğitimine adayan Dr. Maria Montessori'den almıştır (Topbaş, 2013). Maria Montessori eğitimin oluşum sürecini, var olan eğitimin yeniden düzenlenmesi ve yaşamın bizzat içerisinde yer alan doğa ile uyumuna dayandırmaktadır (Schweinhart, 2017). Bu eğitimin temeli, çocuğun doğayla ilişkisine, bireysel gelişimine ve gelişiminin özgür bir şekilde gerçekleşmesine dayanmaktadır (Korkmaz, 2006). Montessori yöntemi kapalı, sabit ve değişmez bir eğitimin 
olmadığı her daim açık bir eğitim sisteminin varlığından söz etmektedir. Sınıfin yeniliklere açık olduğu ve çocukların kendi öğrenmelerini kendilerinin gerçekleştirdiği ve çocuğun gözlemine dayalı bir bakış açısına sahiptir (Lillard, 2013). Çocuktan hareket eden bu yaklaşımın kırmızıçizgisi çevresindeki insanlara zarar vermeyerek en son noktaya kadar genişletilebilmesidir. $\mathrm{Bu}$ kırmızıçizginin varlığı uygulanacak doğal eğitimin, çocuğa hiçbir müdahale yapılmadan içinde bulunduğu çevrenin düzenlemesi ile oluşmaktadır. Okullarda yapılacak kısmi yeniliklerle yöntemin felsefesi ve teorik alt yapısını oluşturmak zordur. Çocukların kendilerini tam anlamıyla ifade edebildikleri ve kendi hızında öğrenmeye dayalı bireysel eğitimi temel alan bir yaklaşım benimsenmelidir. Öğretmenler de çocuklara yardımcı olan konumunda olmaktadır (Çakıroğlu Wilbrandt, 2011). Montessori yöntemi çocuğu merkezine alan bir yaklaşım olup öğretmenin rehber olduğu ve akademik bileşenlere sahip bir program içermektedir (Daoust, 2004).

Montessori sınıf ortamları öğretmen rehberliğinde gerçekleşen, çocukların gelişimi için özenli ortamların yer aldığı ve çocukların doğal yaşamı olarak nitelendirildiği bir alan olarak tanımlanmaktadır. Sınıfta, öğretmen ve materyal birbirinden ayrı düşünülemez. Dr. Montessori çocukların doğal yaşantı sürecine karşı cevap verdiği ve özgür oldukları öğrenme ortamını oluşturmuştur (Lillard ve McHugh, 2019). Öğrenme ortamları olarak adlandırılan sınıflar da olması gereken en önemli unsurlarından biri de Montessori materyalleridir. Bu materyaller çocukların kendi hatalarını kontrol etmelerine sağlayan yapılandırılmış materyallerdir (Akt. Yıldııım Doğru, 2009). Öğretmenler sınıf içerisinde birer gözlemcidir. Çocuğu takip ederek gözlemler, gerekli durumlarda düzen dışına çıkan çocukları yeniden yönlendiren, sınıf içi öğrenmeleri kayıt altına alan ve ebeveynler ile iletişim kuran bilim uzmanlarıdır (Schweinhart, 2017). Öğretmenlerin öncelikli hedefleri ise çocukların kendi kendine başlattıkları faaliyetlerine kaynak olarak hizmet etmeleri ve çocukların birbirleri ile olan iletişiminde açık uçlu firsatlar sunmalarıdır (Stipek ve Byler, 1997).

Montessori eğitim yaklaşımının en önemli özelliği, yöntemin kendine özgü bir eğitim sistemi üzerine kurulmasıdır. Montessori özellikle erken çocukluk üzerine çalışmaya başladığı yıllarda dönemin psikoloji ve eğitim felsefesinin daha çok bir yetişkinin zihnine ve dünya görüşüne dayandığını, öğrenmeyi ve gelişmeyi gerçekten anlamak için yetişkinlerin gözlem yoluyla çocuğun bakış açısını anlaması ve saygı duyması gerektiğini vurgulamıştır (Montessori, 1966; Akt. Gutek, 2004). Çocukların merak duygusunu güdüleyen bu yöntem, sürekli soru soran ve cevaplarını da kendi bulabilen, bağımsız bireyler yetiştirir. Duyusal gelişimleri desteklenen çocuklar ileriki yaşamlarında çevresine ve kendisine saygı duyan, sorumluluk bilinci olan, toplumla uyum içinde yaşamını sürdüren bireyler haline gelirler (Keskin, 2017; Mutlu ve diğerleri, 2012). 
Son yirmi yıldır erken çocukluk gelişimi ile ilgili artan deneysel çalışmalar, altı ve üzeri yaşın eğitime başlamak için geç kalındığını göstermektedir. Bu nedenle okul öncesi eğitimi alan çocukların tüm gelişim aşamalarını destekleyen, kendine yetebilen birey olabilmesini öngören eğitim yaklaşımlarına yönelim oldukça fazladır. Montessori okulları da bunlardan biri olmakla beraber, çocuğun özgür bir ortamda doğal koşullarla birlikte fiziksel, sosyal-duygusal, bilişsel gelişimi desteklemektedir (Özbek Ayaz, 2017). Montessori okullarına giden çocuklar ile diğer okullara devam eden çocukların karşılaştırıldığı çalışmalar, Montessori çocuklarının akranlarına göre akademik ve davranışsal becerilerde daha yüksek puanlar alma eğiliminde olduklarını göstermektedir (Lillard, 2012; Lillard ve Else-Quest, 2006). Ayrıca Türkiye alanyazında da çocukların öz bakım becerileri, problem çözme, bilişsel, sosyal ve motor gelişimleri, el becerileri, fen eğitimi, hazır bulunuşlukları ve akran ilişkileri gibi alanları Montessori yöntemi bağlamında incelenmiştir (Bayer, 2015; Beken, 2009; Bezirci, 2017; Öngören, 2008; Yiğit, 2008; Yücesan ve Özyürek, 2017). Birçok çalışma Montessori yönteminin çocukların öğrenmesini ve gelişimini desteklemek için uygun bir eğitim metodunu olduğunu vurgulamaktadır (Dedeoğlu, 2018; Laski ve diğerleri, 2015; Toran, 2011; Torrence 2012). Ancak Montessori metodu ile ilgili ebeveyn bakış açılarını inceleyen sınırlı sayıda araştırmaya ulaşılmıştır (Bozkurt ve diğerleri, 2019; Ellis, 2017; Epstein, 2015; Hiles, 2018; Parker, 2007; Zarybnisky, 2010). Oysaki çocukları ve yetişkinleri yaşamlarında desteklemek için ebeveynlerin çocuklarının erken eğitimi hakkında düşünme ve hissetme yollarını derinlemesine incelemek önemlidir. Montessori eğitim felsefesi ilkelerini veli-eğitim atölyeleri sayesinde ev-okul ilişkilerini geliştirilmesine yardımcı olmaktadır. Ebeveynlerin ev ortamındaki rolü Montessori sınıf ortamında gerçekleştirilen uygulamalarda çocukların daha deneyimli ve tutarlı olmasını sağlaması adına oldukça önemlidir (Walls, 2018).

Ülkemizde Montessori yöntemi uygulayan okul sayısının her geçen gün artması ebeveynlerin bu yöntemi uygulayan okulları seçtiğini göstermektedir. Yapılan araştırmalar Montessori eğitiminin çocuklar için yararlarını göstermiş olsa da çok az çalışma Montessori eğitimli çocukların ev ortamlarını ve ebeveyn görüşlerini açıkça incelemiştir. Ebeveynlerin çocukları için Montessori okulunu seçmeleri birçok nedene bağlı olmak ile birlikte ebeveynlerin bilgi ve bilinç düzeyleri ile de ilişkilidir. Ebeveynlerin Montessori eğitim felsefesi ve uygulamaları ile ilgili farkındalı̆̆ının olması, eğitimin sadece okul ortamında değil ev ortamında da desteklenmesi ve pekiştirilmesi açısından son derece önemlidir. Montessori eğitim yaklaşımı ancak okul-aile iş birliği içerisinde sürdürülüp ev ve okulun bağlantılı yaşantılar sunması halinde amaçlarının gerçekleşmesi mümkün olmaktadır. Ebeveynlerin, çocuklarına yönelik eğitim değerlerine ve hedeflerine uyduklanı için Montessori eğitimi seçtikleri varsayılmaktadır ancak Montessori ilkeleri genel olarak ebeveynler tarafindan bile yanlış anlaşılmaktadır. Çocuklarını isteyerek Montessori eğitimini seçen ebeveynlerin, evde 
"Montessori”yi ne ölçüde kullandıklarını inceleyen çalışmalar çok azdır. Bu durum çocukların eğitsel çıtılarının amaca ulaşmasında ev ve okul bağlamında kilit görevde olan aile ve ev faktörlerinin tanımlamalarını sınırlandırmaktadır (Walls, 2018). Bu nedenle bu çalışmanın alan yazına katkı sağlayacağı düşünülmektedir. Araştırmanın amacı doğrultusunda araştırmanın soruları aşağıdaki şekilde belirlenmiştir:

1. Ebeveynlerin Montessori okulunu tercih etme sebepleri nelerdir?

2. Ebeveynlerin Montessori eğitim felsefesine ilişkin görüşleri nelerdir?

3. Ebeveynlerin Montessori sınıf ve materyallere ilişkin görüşleri nelerdir?

4. Montessori öğretmenlerine ilişkin görüşleri nelerdir?

5. Montessori okulunun çocuklara kazandırdığı becerilere ilişkin görüşleri nelerdir?

6. Montessori okulundan beklentileri nelerdir?

\section{YÖNTEM}

\section{Araştırmanın Modeli}

Araştırmada ebeveynlerin Montessori okulunu seçme nedenlerini belirlemek için temel nitel araştırma yöntemi kullanılmıştır. Temel nitel araştırmalar, insanların yaşamlarını nasıl yorumladığıyla, dünyalarını nasıl inşa ettikleriyle ve deneyimlerine ne anlam kattıklarıyla ilgilenir. Veriler, görüşmeler, gözlemler ya da doküman analizi yoluyla toplanır. Temel nitel araştırmalarda amaç, araştırmacının katılımcı kişilerin hayatlarını ve deneyimlerini nasıl kavradığını anlamaktır (Merriam, 2018). Bu araştırma kapsamında katılımcıların Montessori okulunu seçme nedenlerini anlamak üzere bu yöntem benimsenmiştir.

\section{Çalışma Grubu}

Araştırmanın çalışma grubunu Montessori okuluna devam eden 4-6 yaş çocukların ebeveynleri oluşturduğundan dolayı amaçlı örnekleme yöntemi seçilmiştir. Amaçlı örnekleme, ortaya konulmak istenen problem, süreç ve olayla ilgili farklı bakış açılarını yansıtan durumların seçilmesinde tercih edilmektedir (Creswell, 2016). Mevcut çalışma 2018-2019 eğitim-öğretim yllında Konya ili bir merkez ilçesinde Montessori okulunda öğrenim gören 4-6 yaş çocukların ebeveynleri ile yürütülmüştür. Bu okulun araştırmaya dahil edilme nedeni, Konya ili bir merkez ilçesindeki Montessori yöntemini uygulayan tek okul olmasıdır. Ebeveynlerin demografik özelliklerine ilişkin dağılım Tablo 1'de gösterilmiştir. 
Tablo 1. Ebeveynlerin demografik özelliklerine ilişkin frekans dağılımı

\begin{tabular}{llll}
\hline Demografik Özellikler & Kategoriler & n & \% \\
\hline \multirow{3}{*}{ Cinsiyet } & Kadın & 25 & 83.3 \\
& Erkek & 5 & 16.7 \\
& Toplam & 30 & 100 \\
\hline \multirow{3}{*}{ Yaş } & $21-30$ & 11 & 36.6 \\
& $31-40$ & 17 & 56.6 \\
& 41 ve üzeri & 2 & 6.7 \\
& Toplam & 30 & 100 \\
\hline \multirow{4}{*}{ Öğrenim Düzeyi } & Ilkokul & 1 & 3.3 \\
& Ortaokul & 1 & 3.3 \\
& Lise & 3 & 10 \\
& Ön lisans & 11 & 36.7 \\
& Lisans & 12 & 40 \\
& Lisansüstü & 2 & 6.7 \\
& Toplam & 30 & 100 \\
\hline
\end{tabular}

Tablo 1'de görüldüğü üzere araştırmaya gönüllü 30 ebeveyn katılmıştır. Bu ebeveynlerden 25’i anne iken 5'i babadır. Ebeveynlerin 11'i 21-30 yaş aralığında, 17'si 31-40 yaş aralığında, 2'si ise 41 yaş ve üstü aralığındadır. Ebeveynlerden 14’ü lisans ve üstü mezunu iken, 1 ebeveyn ilkokul, 1 ebeveyn ise ortaokul mezunudur.

\section{Veri Toplama Araçları}

Araştırmada veri toplama araçları olarak araştırmacılar tarafından oluşturulan kişisel bilgi formu ve yarı-yapılandırılmış görüşme formu kullanılmıştır. Kişisel bilgi formunda ebeveynlerin cinsiyeti, yaşı, öğrenim düzeyi gibi bilgileri içeren sorular bulunmaktadır. Görüşme formunda ise Montessori metodu ile ilgili sekiz açık uçlu soruya yer verilmiştir. Formun geçerliği için öncelikle alanyazın taraması yapılmış, görüşme soruları oluşturulmuş ardından okul öncesi eğitimde uzman iki akademisyenden alınan görüşler doğrultusunda nihai haline karar verilmiştir. Sorular aşağıdaki şekilde belirlenmiştir:

1. Montessori eğitimi veren bir okulu tercih etme sebepleriniz nelerdi? ....̈nem sırasına koysanız en önemli sebepleri neler olurdu? ....Maddeler halinde belirtecek olsanız en önemli nedenleri nasıl siralardınız?

2. Montessori eğitimi felsefesi ile ilgili ne düşünüyorsunuz?

3. Montessori okulunun sınıf ortamı ile ilgili ne düşünüyorsunuz? ....Sınıf ortamının çocuğun gelişiminde önemli bir rol oynadığını düşünüyor musunuz?......

4. Montessori okulunun sınıf içi materyalleri ile ilgili ne düşünüyorsunuz?......Materyallerin çocuğun gelişimine ne yönde katkı sağladığını düşünüyorsunuz? 
5. Montessori okulunun öğretmenleri ile ilgili ne düşünüyorsunuz?

6. Montessori okulunu tercih ederken çocuklarınızın ne gibi kazanımlar elde edeceğini düşünmüştünüz?.........gelişimsel olarak örneğin?.....

7. Montessori okulu, bu okulu tercih etmenizdeki beklentilerinizi karşıladı mı?.....Peki Montessori okulundan beklentileriniz nelerdir?

\section{Verilerin Toplanmas1 ve Analizi}

Araştırmada veriler görüşme tekniği ile toplanmıştır. Görüşme, araştırmada cevabı aranılan sorular çerçevesinde ilgili kişilerden veri toplama şeklinde ifade edilebilir. Görüşmeler belirli bir araştırma konusu veya bir soru hakkında derinlemesine bilgi sağlar (Büyüköztürk ve diğerleri, 2018).

Araştırmanın etik ilkeleri çerçevesinde çalışmaya başlamadan önce okul yönetimi ile görüşülmüş resmi izinler alınmış ve uygulamanın yapılacağı sessiz bir ortam sağlamaları talep edilmiştir. Araştırmaya gönüllü katılmayı sözlü olarak ifade eden ebeveynlerden araştırmacılar tarafindan hazırlanmış bilgilendirilmiş onam formunu imzalamaları istenmiş ve istedikleri zaman görüşmeyi bitirebilecekleri belirtilmiştir. Gönüllü katılmayı kabul eden ebeveynlerden bilgilendirilmiss onam formu aracılığı ile ses kaydı izni alınmıştır. Ses kaydına izin vermeyen ebeveynlerin cevapları araştırmacı tarafından not edilmiştir. Katılımcılar ile her bir görüşme yaklaşık 15-25 dakika sürmüştür. Veriler 2019 yılının Mart ayında toplanmıştır.

Araştırmada toplanan veriler içerik analizi kullanılarak çözümlenmiştir. İçerik analizinde veriler, belirli kurallara dayalı kodlamalarla bir metnin bazı sözcüklerinin daha küçük içerik kategorileri ile özetlendiği sistematik, yinelenebilir bir teknik olarak tanımlanır (Büyüköztürk ve diğerleri, 2018). Her bir araştırma sorusu için alınan cevaplar bilgisayar ortamında yazılı hale getirilmiş, verilen cevaplar doğrultusunda temalar altında kodlamalar oluşturulmuştur.

\section{Araştırmanın Geçerliği ve Güvenirliği}

Araştırmanın betimsel geçerliliği kapsamında veri toplama sürecinde edinilen tüm bilgiler birebir kaydedilmiştir. Maxwell (1992) araştırmanın geçerliliği kapsamında "verilerin doğru şekilde aktarımını" ifade etmektedir (Akt. Güçlü, 2019). Ayrıca çalışma kapsamında birebir alıntılara yer verilmiştir. Araştırmaya katılan ebeveynler Katılımc11 (K1), (K2), (K3) vb. şeklinde isimlendirilmiştir. Araştırmanın güvenirliği kapsamında her bir soru için oluşturulan tema ve alt temalar araştırmacılar tarafindan ayıı ayrı oluşturulmuş ardından bir araya gelinerek ortak temalara karar verilmiştir. 


\section{BULGULAR}

Bu bölümde analizler sonucunda elde edilen bulgulara tema ve alt temalar olarak yer verilmiştir.

\section{Ebeveynlerin Montessori okulunu tercih etme sebepleri}

Ebeveynlerin Montessori okulunu tercih etme sebepleri sorulmuş ve önem sırasına koymaları istenmiştir. Alınan görüşler önem sırasına göre Tablo 2'de gösterilmiştir. Doğrudan alıntılarda sadece temalara ilişkin kısımlara yer verilmiştir.

Tablo 2. Ebeveynlerin Montessori eğitimi veren okulu tercih etme sebepleri (önem sirasina göre)

\begin{tabular}{llll}
\hline Ebeveynlerin Okulu Tercih Etme Sebepleri & & & f \\
\hline Önem 1 & f & Önem 2 & 3 \\
Özgür ortam olması & 18 & Somut kavramlarla öğrenme & 2 \\
Bireysel (Birebir) eğitim verilmesi & 11 & Sınıf ortamı & 2 \\
Farklı bir eğitim anlayışı & 4 & Ahlak/karakter eğitimine destek vermek & 1 \\
Çocuğun mutlu olması/rahat hissetmesi & 2 & Yaratıcı olması & 1 \\
Kişisel becerilerini artırmak & 2 & Sorular üreten/cevaplayan bireyler olması & 1 \\
Doğaya ve doğal yaşama önem verme & 2 & Arkadaşları bu okula gittiği için & \\
Daha iyi/ bilinçli bir eğitim & 2 & & $\mathbf{1}$ \\
Ödül ve ceza olmaması & 1 & & 4 \\
Toplam & 42 & Toplam & 3 \\
\hline Önem 3 & $\mathbf{f}$ & Önem 4 & $\mathbf{1 0}$ \\
Materyal çeşitliliği/gerçek yaşam materyalleri & 8 & Özgüven duygusunun kazandırılması & 3 \\
Öğretmen özellikleri (güven/ilgi/empati) & 5 & Çocuğa önem vermesi & 1 \\
Sorumluluk kazanması & 5 & Montessori eğitim felsefesini bilmesi & 1 \\
Eğlenerek yaşayarak müdahale olmadan öğrenme & 4 & Topluma uyum sağlaması & 1 \\
Öğrenmenin hedeflenmesi & 1 & Akran eğitimi \\
Matematik becerileri & 1 & Ekonomik açıdan uygunluğu & \\
Akademik başarı & 1 & & $\mathbf{1 3}$ \\
Toplam & $\mathbf{2 5}$ & Toplam & \\
\hline
\end{tabular}

Ebeveynlerin cevapları önem sırası doğrultusunda dört ana temada toplanmıştır. Ebeveynlerin verdikleri yanıtların önem sırasına bakıldığında; 18 görüşün okulun ortamının "özgür bir ortam” olması birinci görüş olarak belirtilmiştir. Ebeveynlerden alınan görüşler doğrultusunda 11 görüş ise "bireysel (birebir) eğitim verilmesi” olduğunu belirtmişlerdir. Üç görüş "somut kavramlarla öğrenme” olmasını önem sırasının ikinci bölümünde yer vermiştir. Ebeveynlerin görüşlerinin önem sırasının üçüncü bölümünde ise 8 görüss “materyal çeşitliliği/gerçek yaşam materyalleri” olması şeklinde ifade edilmiştir. Ebeveynlerin tercih sıralarının son bölümünde ise 4 görüş ile "özgüven duygusunun kazandırılması" şeklinde ifade etmişlerdir. 
Özgür ortam olması başlı̆̆1 altında yer alan yanıtlara örnekler

“..Cocuğumun kendisini çok rahat ifade edebiliyor..” (KO)

“...Cocuğumuฉ̨a özgürlügü̈n̈̈ savunmayn ögretiyor..” (K14)

Materyal çeşitliliği/gerçek yaşam başlığı altında yer alan yanıtlara bir örnek

“..Standart dišl, doğal yaşama önem veren bir felsefe...”. (K2)

Sorumluluk kazanması başlığı altında yer alan yanıtlara bir örnek

"..Gelecek hayatında kendi kendine yetebilen bir birey olmasın sağlayacağın düşünüyorum..” (K8)

Özgüven duygusunun kazandırılması başlığı altında yer alan yanıtlara bir örnek

“..Cocuğa özgüven aşılaync etkinlikler sunulması benim için çok önemli..” (K27)

\section{Ebeveynlerin Montessori eğitim felsefesine ilişkin görüşleri}

Ebeveynlerin Montessori eğitim felsefesine ilişkin görüşleri iki ana temaya ayrılmışır. Bir grup ebeveyn bu soruyu çocuğa kazandırdığı beceriler ve davranışlar açısından ele alırken bir grup ebeveyn eğitimsel açıdan felsefesini daha çok vurgulamışır. Bu nedenle her iki farklı bakış açısı “çocuk açısından” ve "eğitim yaklaşımı açısından" olarak iki ana tema altında toplanmıştır.

Tablo 3. Ebeveynlerin Montessori eğitim felsefesine ilişkin görüşleri

\begin{tabular}{llll}
\hline Çocuk açısından & f & Eğitim yaklaşımı açısından & f \\
\hline Tüm gelişim alanlarını desteklemesi & 8 & Bireysel eğitim verilmesi & 7 \\
Akademik başarının artması & 5 & Çocuk merkezli olması & 6 \\
Sorumluluk kazanması & 5 & Günlük yaşam becerileri içeriği olması & 6 \\
Yeteneklerini geliştirilmesi & 4 & Özgür eğitim olması & 5 \\
Özgüven gelişimi & 3 & Doğal malzemelerle yaşayarak öğrenme & 5 \\
Çocuğun kendini ifade edebilmesi & 3 & Çocuğa saygı & 2 \\
Sosyal açıdan geliştirilmesi & 3 & Farklı bir eğitim sistemi & 2 \\
Seçim yapma özgürlüğü tanıması & 2 & Matematiksel bir eğitim & 1 \\
Diğer alanlarla desteklenmesi gerekliliği & 1 & Toplam & 34 \\
Hata yapma ve öğrenme & 1 & & \\
Mutlu birey olması & 1 & & \\
Toplam & $\mathbf{3 6}$ & & \\
\hline
\end{tabular}

Ebeveynlere Montessori eğitim felsefesine ilişkin görüşleri sorulmuş ve toplam 70 görüş sunulmuştur. Felsefeyi çocuğun kazanımları bakış açısından ele alan ebeveynlerin çoğunluğu çocukların gelişimlerini desteklediğini, akademik başarıyı arttığını ve çocuklarda sorumluluk kazandırdığına yönelik görüşs sunmuşlardır. Ebeveynlerin Montessori eğitim felsefesine ilişkin görüşleri belirlerken eğitimsel açıdan ele alanların en çok bireysel eğitim, çocuk merkezli olma, günlük yaşam becerileri içeriği olması başlıkları altında görüş sundukları görülmüştür. 
Tüm gelişim alanlarının desteklenmesi başlığı altında yer alan yanıtlara örnekler;

"Cocuklarmıそın tüm alanlarda gerekli potansiyele ulașmalarnda çok büyük bir etken eğitim sistemi olduğunu düș̈̈nüyorum.” (K12)

"Montessori çocukta özel bir yeteneği kazanmayn sağlar. Çocuğun bir birey olarak tüm özelliklerini mümkün olabilecek en ileri seviyede gelistirmesini bedefler." (K22)

Farklı bir eğitim sistemi başlı̆̆ altında yer alan yanıtlara bir örnek

"Kendim yapabilmem için bana yardım et ve nasıl yapıldiğın bana ögret felsefesini benimseyen Montessori eğitimi, çocuğu yaşamın tüm alanlarnda gelistirmek ve çocuğun henüz ortaya çıkmamıs yeteneklerini kesfedip, ilerlemesini sağlayan bir eğitim sistemidir”. (K4)

Çocuk merkezli olması başlı̆̆ altında yer alan yanıtlara bir örnek

"Bir çocuğa verilebilecek en gürel şey onun çocuk olabilmesi, kendinin yapabileceğini kesfetmesi, kendi gücüne inanarak sabırla onu ortaya çıarmasın beklemesi”. (K16)

Yeteneklerinin geliştirilmesi başlı̆̆ altında yer alan yanıtlara bir örnek

"Montessori çocukta özel bir yeteneği kazanmayn sağlayan ve bu yeteneğin kazamilması ile son bulan duyarlllk. dönemlerini kessfetmiş". (K22)

\section{Ebeveynlerin sınıf ortamına ilişkin görüşleri}

Ebeveynlerin sınıf ortamına ilişkin görüşleri kodlanarak Tablo 4’te sunulmuştur.

Tablo 4. Ebeveynlerin Montessori okulunun sınıf ortamına ilişkin görüşleri

\begin{tabular}{ll}
\hline Sınıf Ortamına İlişkin Görüşler & $\mathbf{f}$ \\
\hline Birebir eğitimin uygulanması & 12 \\
Gelişimi destekleyici bir ortam & 12 \\
Rahat hareket edebilmesi/özgür alanlar sağlaması & 11 \\
Sınıf renklerin sade ve doğal olması & 9 \\
Sınıfın çocuklar için ilgi çekici olması & 5 \\
Çocuklara uygun bir ortam & 5 \\
Sinıftaki nesnelerin günlük yaşamda kullanılması & 3 \\
Matematik eğitimine ilişkin materyaller bulunması & 2 \\
Akran eğitimini desteklemesi & 2 \\
Materyallerin birer tane olması & 1 \\
Toplam & $\mathbf{6 2}$ \\
\hline
\end{tabular}


Ebeveynler sınıf ortamına ilişkin toplam 62 görüş sunmuşlardır. Çoğunlukla çocukların rahat hareket edebilmesi, özgür bir alana sahip olmasını, birebir eğitim uygulanmasını ve ortamın çocuğun gelişiminin desteklenmesinde daha fazla etkili olduğunu belirtmişlerdir.

Rahat hareket edebilmesi/ özgür alan başlı̆̆ı altında yer alan yanıtlara bir örnek

"Simflarm, cocuklarm rahat bir sekilde tüm istedikleri materyal ve oyuncaklara yetisebilmesi, kendi bașina karar veriyor olmasi gelisimi süresince etkilidir”. (K1)

Gelişimin desteklenmesi altında yer alan yanitlara örnekler

“...Sinrf düzeni ile her çocuğa ayn seviyede eğitim vererek gelişimine daba kolay katku sağlyyor..” (K21).

"Sinnf ortamı sade, yaşamm içinden. Cocuğumun ulaşabileceğgi rahatça istediğinde alabileceği ve doğal malzemelerden oluşan bir sinf. Tabi ki çocuğumun gelisiminde önemli rol oynuyor. Sakin ve sade ortamda kendinin gücünü ve deneyimlerini sakince ortaya çıkarabilir. Rahatça ögrenimine vakit ayırabilir.” (K16)

Sınıftaki nesnelerin günlük yaşamda kullanılması başlığı altında yer alan yanıtlara bir örnek

“...Etrafindaki nesnelerin günlük yaşama yakın olması ve bu yüzden çocuğumun evinde gibi bissetmesi çok önemli”. (K30)

\section{Ebeveynlerin sınıf içi materyallere ilişkin görüşleri}

Ebeveynlerin sınıf içi materyallere ilişkin görüşleri çocuğa ilişkin kazanımlar ana teması altında toplanmış ve kodlar bu tema altında oluşturulmuştur. Ebeveynlerin görüşleri Tablo 5'te sunulmuştur.

Tablo 5. Ebeveynlerin Montessori okulunun sınıf içi materyallerine ilișkin görüșleri

\begin{tabular}{ll}
\hline Çocuğa İlişkin Kazanımlar & f \\
\hline Eğitici ve öğretici & 11 \\
Eğlenerek öğreniyor & 9 \\
Çocuğun gelişimine uygun & 8 \\
Matematiğini geliştiriyor & 6 \\
Her kazanıma uygun materyal sunuyor & 5 \\
Sağlık açısından ahşap olması önemli & 5 \\
Hayal gücünü destekliyor & 3 \\
Konsantrasyon arttırıyor & 3 \\
Hata yaparak öğreniyor & 2 \\
Özgüvenini geliştiriyor & 2 \\
Çocuğun aktif olmasını sağlıyor & 1 \\
El becerilerini arttıriyor & 1 \\
Merakı destekliyor & 1 \\
Toplam & 57 \\
\hline
\end{tabular}


Tablo 5'te görüldüğü üzere ebeveynlerin Montessori okulunun sınıf içi materyallerine ilişkin görüşlerine bakıldığında toplam 57 görüş sunmuşlardır. Görüşlerin 11’i materyallerin eğitici ve öğretici olması başlı̆̆ı altında toplanırken görüşlerden 9’u ise çocukların materyallerle eğlenerek öğrendikleri temasında toplanmıştır.

Materyallerin eğitici ve öğretici olması başlığı altında yer alan yanıtlara örnekler

"Materyaller eğitim- ögretim süreci için önemlidir. Kalıc ögrenmeler, kolay öğrenmeleri să̆lar. Bireyi sürece aktif dabil eder". (K5)

“.....Çok doğru her materyalin özenle, eğitici olarak hazırlanması cok önemli. Cocuğun gelisimine göre materyal seçilmesi ona uygun materyal üzerinde çalısılması çocuğun ögrrenmeye hažr tespitiyle dengede gitmesini önemseyen "bir eğitim.." (K2)

Matematik materyalleri başlı̆̆ı altında yer alan yanıtlara bir örnek

"Materyaller çocuğumun zelkâsına, gelişimine yönelik çok büyük katkr sağlamaktadır. Özellikle matematik materyalleri çocuğumun somut șekilde ögrenmesine, ę̧bere dayah olmadan bilissel gelişiminin artmasına neden olmaktadır. Toplama-çıkarma işlemlerini rahathkla yapabilmektedir”. (K28)

\section{Ebeveynlerin öğretmenler ile ilgili düşünceleri}

Ebeveynlerin öğretmenler ile ilgili görüşleri Tablo 6'da verilmiş, görüşler öğretmen nitelikleri ana teması altında toplanmış ve bu temaya uygun kodlamalar yapılmıştır.

Tablo 6. Ebeveynlerin öğretmenlere ilişkin görüşleri

\begin{tabular}{ll}
\hline Öğretmen Nitelikleri & f \\
\hline İlgili ve başarllı & 13 \\
İşini seven ve güler yüzlü & 11 \\
Donanımlı/bilinçli ve farklı & 9 \\
Bireysel farkllıkları önemseyen/çocuğa saygılı & 7 \\
Rehber bir rol benimsemiş & 5 \\
Öğretme kaygısı taşımayan & 2 \\
Toplam & 47 \\
\hline
\end{tabular}

Çalışma grubundaki 30 ebeveyne Montessori okulunun öğretmenleri ile ilgili görüşleri sorulmuştur ve toplam 47 görüş alınmıştır. Ebeveynler öğretmenlerin "İlgili ve başarılı", "İşini seven ve güler yüzlü”, "Donanımlı/bilinçli ve farklı" ve "Bireysel farkl11ıkları önemseyen” nitelikte olduklarını belirtmişlerdir.

Donanımlı/bilinçli ve farklı başlığı altında yer alan yanıtlara bir örnek "Bilinçliler, bu felsefenin amacm iyi kavramıs olmalar eğitimi daba kaliteli hale getiriyor”. (K2)

Öğretme kaygısı taşımayan başlığı altında yer alan yanıtlara bir örnek 
“... Hedefleri ögrenmeye zorlamak değil, ögrenmeye rehber olmak istemeleri gayet güzel düssünce bence”. (K3)

Bireysel farklılıkları önemseyen başlı̆̆ altında yer alan yanıtlara bir örnek

“... Kendilerine ö̊gü birey olduklarna ve kendi kapasiteleri doğrultusunda ögrendiklerine odaklayarak yaşama hąurlar". (K22)

\section{Ebeveynlerin okulun çocuklarına katkılarına ilişkin görüşleri}

Ebeveynlerin okulun çocuklarına olan katkıları ile ilgili olarak toplanan görüşler analiz edilerek tablolaştırllmıştır. Ebeveynlerin görüşlerine Tablo 7'de yer verilmiştir.

Tablo 7. Ebeveynlerin Montessori okulunun çocuklarına kazandırdığı özelliklere ilişkin görüşleri

\begin{tabular}{ll}
\hline Çocukların kazandı̆̆ı özellikler & $\mathbf{f}$ \\
\hline Özgüvenli ve kararlarını alabilen & 20 \\
Yaşına uygun gelişim gösteren & 11 \\
Özgür ruhlu ve mutlu & 9 \\
Kendi işini kendi yapan (günlük yaşam becerileri) & 8 \\
Meraklı ve hayal gücü yüksek & 6 \\
Dikkatli & 5 \\
Sorumluluklarını bilen & 4 \\
Saygı duyulan & 3 \\
Ahlaklı & 1 \\
Hatasını düzeltebilen & 1 \\
Toplam & $\mathbf{6 8}$ \\
\hline
\end{tabular}

Tablo 7'de görüldüğü üzere ebeveynlerin Montessori okulunun çocuklara katkıları sorusuna verdikleri cevaplar "çocukların kazandığı özellikler" ana teması altında sunulmuştur. Ebeveynler “Özgüvenli ve kararlarını alabilen” alt teması altında 20 görüş, “yaşına uygun gelişim gösteren” alt teması altında 11 görüş ve "özgür ruhlu ve mutlu" çocuklar olması teması altında 9 görüş bildirmişlerdir.

Özgüvenli ve kararlarını alabilen başlı̆̆ı altında yer alan yanıtlara bir örnek

"Ileriki okul hayatmda kendine güvenen, özgüveni yüksek olan, ders çalısmasm prensip edinmis, kendi kararlarm verebilen bir birey yetismesini istedik". (K1)

Özgür ruhlu ve mutlu çocuk başlı̆̆1 altında yer alan yanıtlara bir örnek

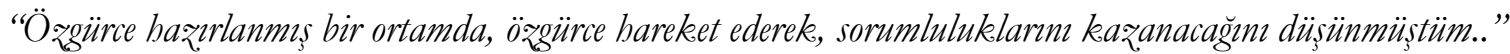
(K11)

Meraklı ve hayal gücü yüksek başlığı altında yer alan yanıtlara bir örnek “... Hayal gücünün farkına vararak etkinlikler olusturacağın düşünüyorum”. (K29) 


\section{Ebeveynlerin okuldan beklentileri}

Ebeveynlerin okuldan beklentileri ve beklentilerinin karşılanıp karşılanmadığına ilişkin sorulara verdikleri yanitlar Tablo 8 ve Tablo 9'da verilmiştir.

Tablo 8. Ebeveynlerin Montessori okulunun beklentilerinin karșılanmasına ilișkin görüșleri

\begin{tabular}{ll}
\hline Beklentilerin Karşılanmasına İlişkin Görüşler & f \\
\hline Evet, karşıladı beklediğim gibi & 12 \\
Kesinlikle karşılladı & 10 \\
Beklediğimden daha iyisiyle karşıllaştım & 6 \\
Henüz okul bitmedi & 1 \\
Cevap vermedi & 1 \\
Toplam & $\mathbf{3 0}$ \\
\hline
\end{tabular}

Ebeveynlerin Montessori okulunu tercih etme sebeplerinin sonucunda beklentilerinin karşılanıp karşılanmadığı sorulmuş buna ilişkin yanıtlar alınmıștır. Ebeveynlerin 12'si "Evet karşıladı, beklediğim gibiydi”, 10’u “Kesinlikle karşıladı", 6’sı "beklediğimden daha iyisi ile karşılaştım”, 1’i “Henüz okul bitmedi” ve 1’i “cevap vermedi” şeklinde belirtmişlerdir.

Tablo 9. Ebeveynlerin Montessori okulunun beklentilerine ilişkin görüşleri

\begin{tabular}{ll}
\hline Okuldan beklentileri & f \\
\hline Tüm gelişim alanlarının desteklenmesi & 10 \\
Çocuğun mutlu olması & 6 \\
Çok memnunum & 6 \\
Eğitimde aynı kararlılı̆̆ı sürdürmeleri & 4 \\
Birebir eğitiminin devam etmesi & 3 \\
Çocukların kendini özgürce ifade edebilmesi & 3 \\
Okulun rehber olması & 3 \\
İlköğretim ve lise kademesinde eğitimin devamı & 2 \\
Çocukların yeteneklerini geliştirilmesi & 2 \\
Sorumluluklarını bilen bireyler yetiştirmeleri & 1 \\
Değerlerimize önem verilmesi & 1 \\
Toplam & 41 \\
\hline
\end{tabular}

Çalışma grubundaki 30 okul ebeveyne "Peki bundan sonraki süreçte Montessori okulundan beklentileriniz nelerdir?” sorusu ve toplam 41 görüss alınmıştır. Ebeveynlerden alınan görüşlere bakılarak "Çocuğun mutlu olması", "Tüm gelişim alanlarının desteklenmesi”, "Eğitimde kararlılık" ebeveynlerin okuldan beklentileri açısından dikkat edilen görüşler olarak belirlenmiştir.

Çocuğun mutlu olması başlı̆̆ı altında yer alan yanıtlara bir örnek

"Fiziksel, ziłinsel, gelişimsel olarak mutlu, kendi kendine yeten bireyler yetismesi”. (K8)

Daha fazla materyal ile tanışması başlı̆̆ı altında yer alan yanıtlara bir örnek 
"Cocuğumun daha fazla hayata dair materyal ile tanısması. Böylelikle okuldan da hayattan da zevk alacağmı düsünüyorum. Yeni kavramlar merak ve heyecan uyandrrr". (K11)

Birebir eğitimin devam etmesi başlı̆̆ı altında yer alan yanıtlara bir örnek

"Sinf içinde her bireyin öz̧el olduğu unutulmamah ve kişiye özel bireysel eğitimin yapılması". (K26)

İlköğretim ve lise kademesinde de eğitimin devamı başlı̆̆ı altında yer alan yanıtlara bir örnek

"Cocuğum için bu okulun ortaokul ve lise hayatında da devamının olmasım çok isterim. Hayata dair daba çok, seyleri somut şekilde öğrenebilmesi için”. (K30)

\section{SONUÇ ve TARTIŞMA}

Ebeveynlerin bir eğitim modelini başka bir eğitim modeline tercih etme sebepleri alanyazına bakıldığında bugüne kadar yeterince incelenmediği görülmektedir. Bu araştırma alanyazındaki bu boşluğu dolduracak fikirler ortaya koymaktadır. Araştırma sonuçları ebeveynlerin sınırlı sayıda nedenden dolayı Montessori okullarını tercih ettiklerini göstermektedir. Montessori okullarını diğer okullardan farklı kılan birkaç özelliği üzerine daha çok durulduğunu görülmektedir. Bireysel (birebir) eğitim, özgür ortam, materyal çeşitliliği ve sınıf ortamının çocuklara uygunluğu gibi nedenler daha çok ön plana çıkmaktadır. Bu bölümde araştırma sonuçları ayrıntılı bir şekilde ele alınmıştır. Buna göre ebeveynlerin Montessori okulunu tercih etmedeki sebepleri sorulduğunda ebeveynlerin yarısından fazlasının çocuğa özgür bir ortam sağlanması, bireysel eğitimin olması, özgüven duygusunun kazandırılması görüşü üzerinde durmuşlardır. Ayrıca her dört ebeveynden biri de materyallerin gerçek yaşama özgü, çeşitli ve çocuğa uygun olmasının önemli olduğunu belirtmişlerdir. Bu bulgular Montessori yönteminde bireysel olarak çocuğa odaklanmanın, ona sağlanan sınıf ortamı sayesinde kendi içsel motivasyonu ile kendini yöneten çocuklar olmasına yardım eden bakış açısını destekler yöndedir. Araştırma bulguları ile paralel olarak Hiles'ın (2015, 2018) çalışmalarında Montessori ilkelerine olan ilginin, Montessori okulunda sağlanan birebir eğitimin ve ebeveynlerin beklentilerini karşılaması, Montessori sınıf ortamının çok yönlü ve gerçek yaşam bağlantısı ile ilişkili olduğunu belirtmiştir. Yine benzer şekilde Zarybnisky (2010) Montessori ebeveynlerinin en önemsediği noktanın bireysel eğitim noktası olduğunu belirtmiştir. Sınıf içi materyallerin çalışmalarda ebeveynlerin dikkat ettiği bir nokta olarak ortaya çıkmıştır. Örneğin; Ellis (2017) çalışmasında sınıf içi materyallerin ebeveynlerin önemsediğini; Irving (2017)'in çalışmasındaki ebeveynler manipulatif materyallerin Montessori sınıflarını geleneksel sınıf ortamından farklılaştırdığını belirtmiştir. Mevcut araştırma sonuçları Montessori eğitim felsefesinin gerçek materyal kullanımı ve çeşitliliği ile diğer eğitim felsefeleri ilkeleri arasında farklılık oluşturduğunu ve ebeveynlerin materyallere dikkat ettiğini göstermektedir. 
Araştırmaya katılan ebeveynlerin Montessori eğitim felsefesine ilişkin görüşlerine bakıldığında, ebeveynlerin bakış açılarının iki alt temada toplandığı görüşmüştür. Felsefeyi çocuğun kazandığ1 beceriler olarak ele alan ebeveynler çoğunlukla eğitimin çocukların tüm gelişim alanlarını desteklendiğini, akademik başarı sağladığını ve sorumluluk kazanmasında önemli rol oynadığını vurgulamışlardır. Örneğin katılımcı 1 "Çocukların seçim yaparak materyalleri kullanma gibi birçok sorumluluk verilmesi bu okulların çocuk gelişimindeki önemi artırmalıdır. Bu yüzden Montessori eğitimi veren bu okulu seçtik." şeklinde ifade etmiştir. Eğitim yaklaşımı açısından bakış açısı sunan ebeveynlerin en çok görüş bildirdiği konu ise bireysel eğitim ve eğitimin çocuk merkezli olma noktasıdır. Montessori eğitim felsefesinde her çocuğun kendi bireysel hızına ve gelişimine önem verilir bu nedenle çocuğun bireyselliği ön plandadır (Acay, 2018). Ebeveynlerin bu noktaya değinmesi geleneksel eğitim programının aksine her çocuk için bireysel eğitim planlanmasını önemsediklerini de ortaya çıkarmaktadır. Ayrıca çocuk merkezli eğitim noktası dikkat edilmesi gereken bir konudur. Hali hazırda devlet okullarının müfredatı da çocuk merkezli bir anlayışla sahip olsa da Montessori sınıflarında çocukların ilgi, ihtiyaç ve yeteneklerinin ön plana çıkarılması ve önemsenmesi, geleneksel eğitim bakış açısından ayrılan dikkat çekici bir noktadır (Acay, 2018; Bayer ve Çağdaş 2018). Ebeveynlerin bir diğer çoğunlukla görüş bildirdiği konu ise “Günlük yaşam becerileri” ve "Özgür eğitim” görüşleridir. Montessori eğitim yaklaşımında günlük yaşam becerilerine önem verilmesi çocuğun tüm gelişim alanlarının gelişmesine, çocukta hareket denetiminin oluşmasına, el-göz koordinasyonu sağlamasına yardımcı olmaktadır (Cai, 2009).Günlük yaşam becerileri çocuğun çalışma düzenini oluşturduğu, materyalini seçtiği, ev ortamında yapmış olduğu görevleri pekiştirdiği bir alandır. Ebeveynlerin günlük yaşam becerilerine odaklanmaları ve özgür eğitim görüşü üzerinde yoğunlaşmaları Montessori yönteminin ebeveynler tarafından benimsendiği ve yöntemin gerektirdiklerinin farkında olduklarını göstermektedir.

Ebeveynlerin sınıf ortamı ile ilgili görüşlerine bakıldığında; birebir eğitim uygulamaları, gelissimi destekleyen bir ortam oluşu, çocuğun rahat hareket edebilmesi ve çocuğa özgür alanların sağlanması başlıca görüşler arasındadır. Montessori eğitiminde sınıf ortamı eğitimden bağımsız düşünülemez. Çocukların gelişimsel ihtiyaçları doğrultusunda öğretmen tarafindan hazırlanan sınıflar çocuklara bağımsız bir şekilde çalışma ortamı sağlamaktadır. Bu nedenle materyaller ve mobilyalar çocuğun çalışabileceği boyutlardadır (Topbaş, 2013). Ayrıca ebeveynlerin önemsediği ve Montessori’nin de üzerinde önemle durduğu sinıf içerisinde çocuğun özgür hareket etmesi öğrenmenin gerçekleşmesinde motivasyon sağlayan bir özelliktir (Durkaya, 2019). Ebeveynlerin sınıf ortamı ile ilgili düşünceleri ve beklentileri Montessori sınıf ortamı konusunda davranışsal beklentileri karşılar niteliktedir. 
Montessori okulunun sınıf içi materyallerine ilişkin ebeveynlerin görüşlerine bakıldığında, ebeveynlerin çoğunlukla materyalleri eğitici ve öğretici buldukları çocuklarının eğlenerek öğrendiklerini hem gelişimlerine uygun doğal materyaller olduğu hem de matematik gelişimleri için özellikle önemli olduğunu belirtmişlerdir. Benzer şekilde Ellis (2017) çalışmasında ebeveynlerin özellikle matematik müfredatı ve materyallerini çok önemsediklerini bulmuştur. Kahn’a (1990) göre ebeveynler çocuklarının Montessori okullarında almış oldukları eğitimin çocukların yetiştirilmesinin bir uzantısı olarak bakmaktadırlar. Montessori eğitim felsefesi ilkelerine olan ilgileri nedeniyle ebeveynler Montessori eğitimi hakkında her firsatta bilgi arayışı içerisindedir. Okul yaşantısının geleneksel eğitim ile olmadığını doğal yaşamla desteklendiğini vurgulamaktadır. Montessoriłye göre çocuğun doğa ile doğadaki gerçek nesnelerle teması da son derece önemlidir. Bu nedenle bir Montessori sınıfinda mevcut eşyalar oyuncaklar değil, gerçek nesnelerdir (Oğuz ve Köksal Akyol, 2006). Benzer olarak bu araştırma kapsamında da ebeveynler özellikle geleneksel sınıf ortamlarından farklı olması, doğal malzemelerin kullanılmasının önemi üzerinde görüş sunmuşlardır. Montessori sınıflarında çocukların sağlı̆̆ı için yararlı doğal ahşap malzemelerin yer alması ve kullanılması, materyallerin plastik türü malzemeler olmaması çocuklar ve ebeveynler için çok önemlidir. $\mathrm{Bu}$ araştırma sonuçları ebeveynlerin Montessori okullarını tercih ederken çocuklarının alacakları eğitim kadar fiziksel sağlıklarına da önem verdikleri görüşü ortaya çıkmaktadır.

Araştırmaya katılan ebeveynlerin Montessori okulunun öğretmenleri ile ilgili görüşlerine bakıldığında ilgili, başarılı, donanımlı ve bireysel farklılıkları önemseyen öğretmenler oldukları yönünde görüşler sunmuşlardır. Hennigan'ın, (2008) Montessori sınıflarında öğretimde karar verme üzerine yaptığ1 araştırmasında Montessori öğretmenlerinin bilişsel, sosyo-duygusal ve fiziksel gelişim de dahil olmak üzere öğrencilerinin çok ayrıntılı gözlemledikleri ve gözlemlerini yaparlarken de çok çeşitli davranışsal bilgilere odaklandıkları sonucuna ulaşmıştır. Ayrıca Montessori okullarında öğretmenlerin birer gözlemci olarak yer alması ve gerekli durumlarda çocuklara rehberlik etmesi ve onları yönlendirmesi araştırmada ebeveynlerin bu okulu tercih etmesindeki nedenler ile paralellik göstermektedir.

Ebeveynlere Montessori okulunun okul öncesi dönem çocuğuna kazandırdığı beceriler ve tutum ve davranışlar sorulduğunda ebeveynler çocuklarının bu okula gitmeye başladıktan sonra daha özgüvenli ve kararlarını alabilen, yaşına uygun gelişim gösteren, özgür ruhlu ve mutlu çocuklar olduğunu bildirmişlerdir. Benzer olarak Bozkurt ve diğerleri (2019) ebeveynler ile yaptıkları çalışmalarında çocukların kendi işini kendi yapabilme becerisi kazandığını ifade etmissledir. Montessori (1967) çocukların giyinmek, beslenmek veya temizlemek gibi şeyleri öğrenmelerine izin 
vermenin, bunları çocuk için yapan yetişkinden çok daha fazla zaman alıcı olduğunu kabul etse de, bunun bir eğitim olduğuna, bağımsızlığın geliştirilmesinde özgürlüğe ve mutluluğa ulaşmanın anahtarı olduğunu belirtmiştir (Akt. Ellis, 2017). Montessori eğitim yönteminin okul öncesi dönem çocuğuna kazandırmak istediği başlıca özellikler (Lillard ve Jessen, 2015) mevcut araştırma sonuçlarında yer alan ebeveynlerinin görüşleri ile benzerlik taşımaktadır.

Son olarak ebeveynlere Montessori okulundan beklentilerinin neler olduğu ve okulun beklentilerini karşılayıp karşılamadıkları sorulmuştur. Ebeveynlerden alınan görüşlere bakılarak çocukların tüm gelişim alanlarının desteklenmesi ve çocuğun mutlu olması ebeveynlerin okuldan beklentileri açısından dikkat edilen görüşlerdir. Ayrıca ebeveynlerin yarısından fazlası okuldan beklentilerinin karşılandığını ve çok memnun olduklarını dile getirmişlerdir. Ilgar’ın (2013) çocukları Montessori programlarına katılan ebeveynlerin ve velilerin algılarını incelediği çalışmasında ailelerin program hakkında bilgi sahibi olduklarını, evlerinde Montessori eğitim programına devam ettiklerini ve aileler, çocukları için bu okulu tekrar seçebileceklerini belirtmişlerdir. Mevcut araştırma sonuçları da ebeveynlerin Montessori okullarından memnun olduklarını ve çocuklarının mutlu ve kendine güvenen bireyler olma fikrinden oldukça etkilendiklerini göstermektedir.

Araştırmanın genel olarak sonuçlarına bakıldığında ebeveynlerin Montessori yöntemine bakış açılarının olumlu olduğu düşünülmektedir. Benzer sonuçlar ebeveynlerin alg1, düşünce ve görüşlerinin incelendiği çalışmalarla da ortaya çıkmıştır. Bozkurt ve diğerleri (2019) Montessori okulunu tercih eden ebeveynlerin okul ile ilgili algılanını incelediği çalışmalarında ebeveynlerin yönteme dönük algılarının olumlu olduğunu ortaya koymuştur. Ellis (2017) ebeveynlerin Montessori 'ye ilişkin bakış açılarının olumlu olduğunu, eğitimin çocukların sosyal ve duygusal gelişimini, içsel motivasyonu ve akademik becerilerini, özellikle matematik becerilerini geliştirici bulduklarını ifade etmiştir. Mevcut araştırma sonuçları alanyazın çalışmalarının sonuçlarıyla benzerdir. Ancak önemli bir noktayı belirtmekte fayda görülmektedir. Her ne kadar mevcut çalışma içerisinde ebeveynler yöntemi faydalı bulsa da metodun özellikle birkaç önemli noktasına daha çok değinmişken felsefenin önemli bileşenlerinden olan bazı unsurlara hiç değinmemişlerdir. $\mathrm{Bu}$ unsurlar; çocuğa sayg1, oto-eğitim (öz-denetimli), emici zihin, duyarlılık dönemleri ve çoklu yaş gruplarıdır. Oysaki bu ilkeler Montessori yönteminin temelini oluşturmaktadır. Her ne kadar ebeveynler Montessori eğitim felsefesine ve sınıf ortamlarına ilgi duysa da yöntemi tam anlayabildiklerini söylemek mümkün değildir. Ebeveynlerin çoğunlukla birebir eğitim, özgür ortam vurgusu sadece Montessori bilinci ile değil özel okul tercih sebebi olarak da yorumlanabilir. Örneğin; Zarybinski (2010) ebeveynlerin neden devlet ve özel Montessori okullarını seçtiğini inceleyen bir çalışmasında, ebeveynlerin değerleri ve eğitim görüşleri genellikle benzer olsa da, özel 
okul ebeveynleri akademik sonuçlara öncelik verirken, devlet okulu ebeveynlerinin ücretsiz eğitime öncelik verme eğiliminde olduğunu bulmuştur. Mevcut çalısmada ebeveynlerin felsefe ile ilgili görüşlerini sunarlarken akademik başarı noktasına da dikkat çektikleri görülmüştür. Benzer şekilde Epstein (2015), araştırmasında öğretmenler ailelerin en yüksek beklentisinin "akademik ilerleme" olduğunu belirtmişlerdir. Bu gibi okul seçme nedenleri yöntemin tam anlaşılamaması durumunu ortaya çıarabilmektedir. Montessori yönteminin tam anlamıyla anlaşılamaması ise ebeveynler tarafından içselleştirilmemesine ve evde devam etmesi gereken tutum ve davranışlara yansımayacağını göstermektedir. Ebeveynlerin yöntemin değerini tam anlamaması felsefeye uygun olmayan yollara başvurmalarına sebep olabilir (ödül-ceza uygulama, çocuğu teste tabi tutma, başarı notlarını önemseme gibi). Felsefeye uygun olmayan davranışların ortaya çıkışı çocukların yaptıkları şeyi neden yaptıkları konusunda kafa karışıklıkları yaşamasına, ev ve okul arasında tutarsız uygulamalara sebep olabilir. Bu durum felsefenin tam anlamıla amacını yerine getirmesine engel olabileceği düşünülmektedir. Bu noktada ebeveyn eğitimlerinin öneminden bahsetmek mümkündür. Irving (2017) ebeveynlerin Montessori eğitimi aldığı çalışmasında ebeveynlerin bilgilerinin geliştiği, evdeki standart Montessori uygulamalarının arttı̆̆ı ve katılımcıların Montessori felsefesi hakkında daha derin sorular sormaya başladığını belirtmiştir. Benzer şekilde Pickard (2019) ebeveynlerin Montessori eğitimlerinin çocuklarına okul karar vermede daha etkili ve bilinçli davrandıklarını bulmuştur.

$\mathrm{Bu}$ çalışmanın bulgularından elde edilen sonuçlar doğrultusunda ebeveynlerin çocuklarını Montessori okuluna gönderme nedenlerine ilişkin öneriler şu şekilde değerlendirilebilir;

- Araştırma sonuçlarına bakıldığında ebeveynlerin Montessori okuluna gönderme sebeplerinin ebeveynlerin bu eğitim yönteminde bilinçli olarak bazı öğelere (özgür ortam, birebir eğitim, materyallerin çocuklara uygun olması gibi) değindiklerini göstermektedir. Ancak yöntemin bazı önemli ilkelerini (oto-eğitim, duyarlılık dönemleri, çoklu yaş grupları gibi) göz ardı ettikleri görülmüştür. Bu nedenle Montessori eğitimi ile ilgili bundan sonra yapılacak çalışmalarda ebeveynlerin ilkeleri anlama ve farkındalıklarının daha fazla araştırılması ve bu ilkelerin ebeveynlerin kararlarını ne ölçüde etkilediğinin incelenmesi eğitim yönteminin doğru uygulanmasında fayda sağlayacağı düşünülmektedir.

- Çocuklarını Montessori okullarına gönderen ebeveynlerin Montessori eğitim felsefesine yönelik bilgi düzeylerinin iyi olduğu Montessori okullarının yaygınlaştırılmasında Milli Eğitim Bakanlı̆̆ ile bağlantılı projeler yapılarak özel okul yerine ebeveynlerin tercih edebileceği devlet okul modeline dönüştürülebilir. 
- Evde ve okul ortamında işbirliği ile sağlanan eğitim ya da evde aynı tutum ve davranışlar ile pekiştirilmesi çocuklarda daha kalıcı öğrenmeler sağlayacağı için öğretmenlerin ev ziyaretleri ile ebeveynlere çocuklarının eğitimlerini destekleyecek etkinlik örnekleri konusunda destek olabilirler.

- Montessori eğitimi yalnızca çocuğa yönelik bir eğitim süreci olarak sınırlandırmak mümkün değildir. Ebeveynlerin bu konuda ki bilgisi, sürece olan katkısı bu eğitimin önemli bir parçasıdır. Bu nedenle daha önce Montessori okullarına devam eden çocukların ebeveynlerinden görüş alınan daha geniş örneklemlerle çalışmalar yapılabilir.

\section{KAYNAKÇA}

Acay, E. (2018). Okul öncesi çocuklarmm renk ve doku bilgilerini edinmelerine Montessori eğitim yönteminin etkililiği. Yayımlanmamış yüksek lisans tezi, Necmettin Erbakan Üniversitesi, Eğitim Bilimleri Enstitüsü, Konya.

Bayer, A. \& Çağdaş, A. (2018). Montessori yönteminin okul öncesi (36-66 ay) çocuklarmmn öz bakım becerilerine etkisinin incelenmesi. Ë̆itim Bilimleri Araştırmaları. Ankara: Çizgi Kitabevi.

Bayer, A.(2015). Montessori yönteminin okul öncesi (36-66 ay) çocuklarmm öz bakım becerilerine etkisinin incelenmesi. Yayımlanmamış yüksek lisans tezi, Selçuk Üniversitesi, Sosyal Bilimleri Enstitüsü, Konya.

Beken, S. (2009). Montessori yöntemi etkinliklerinin 5-6 yaș çocuklarmm el becerilerinin gelisimine etkisi. Yayımlanmamış yüksek lisans tezi, Adnan Menderes Üniversitesi, Eğitim Bilimleri Enstitüsü, Aydın.

Bezirci, H. (2017). Montessori yönteminin anaokulu cocuklarn akran iliskilerine ve akran tepkilerine etkisinin incelenmesi. Yayımlanmamış Yüksek Lisans Tezi, Selçuk Üniversitesi, Sosyal Bilimleri Enstitüsü, Konya.

Bozkurt, E., Kölemen, E.B., Abanoz, T. \& Ulutaş, İ. (2019). Çocukları Montessori eğitimi alan ebeveynlerin "Montessori Eğitimi”" algisı. Akademik. Sosyal Araştirmalar Dergisi, 92 (7), 239251. Doi: 10.16992/ASOS.14916

Büyüköztürk, Ş., Çakmak, E. K., Akgün, Ö. E., Karadeniz, Ș. \& Demirel, F. (2018). Bilimsel araștırma yöntemleri. Ankara: Pegem Akademi.

Cai, Z. (2019). SWOT analysis on the sinicization of montessori's children education. Journal of Contemporary Educational Research, 3(4), 60-65.

Creswell, J. W. (2016). Nitel araştırma yöntemleri, Beș yaklașıma göre nitel araștırma ve araștırma deseni. M. Bütün ve S.B. Demir (Çev. Ed.),(3. Basımdan çeviri). Ankara: Siyasal Kitabevi.

Çakıroğlu Wilbrandt, E. (2011). Çocuk Eğitimi Sanatı. İstanbul: Sistem Yayıncılık.

Daoust, J. C. (2004). An examination of implementation practices in Montessori early childhood education. Unpublished doctoral dissertatinon, University Of California, Berkeley. 
Dedeoğlu, S. (2018). MEB okul öncesi eğitim programı ve Montessori programma göre eğitim alan çocuklarm bilissel gelisim ve sosyal yetkinliklerinin karşılaștırlmal olarak incelenmesi. Yayımlanmamış yüksek lisans tezi, Necmettin Erbakan Üniversitesi, Eğitim Bilimleri Enstitüsü, Konya.

Durkaya, S. (2019). MEB okul öncesi eğitim programına ve Montessori yaklaşımına göre eğitim alan anasınfi çocuklarmm sezgisel matematike yeteneklerinin karşılaștırlması. Yayınlanmamış yüksek lisans tezi. Marmara Üniversitesi, Eğitim Bilimleri Enstitüsü, İstanbul.

Ellis, K. E. M. (2017). How Do Parents Think and Feel about Early Childhood Montessori Education? Unpublished doctoral dissertation, Mills College, USA.

Epstein, A.(2015). Montessori early childhood teacher perceptions of family priorities and stressors. Journal of Montessori Research, 4(1),1-13.

Gutek, G.L. (2004). The Montessori Method: the origins of an educational mnovation: including an abridged and annotated edition of maria montessori's the montessori method. UK: Rowman \& Littlefield Publishers, Inc

Güçlü, İ. (2019). Sosyal bilimlerde nitel araştırma yöntemleri. Ankara: Nobel Yayın.

Heckman, J. J. (2011). The economics of inequality: The value of early childhood education. American Educator, 35(1), 31-35.

Hennigan, E. (2008). Assessment and instructional decision-making in montessori early childhood classrooms. Unpublished master thesis, The Faculty of the Kalmanovitz School of Education Saint Mary's College of California.

Hiles, E. (2015). Measuring parent perception and understanding of Montessori education in three Massachusetts Montessori schools. Theses and Dissertations. 644. Erissim tarihi (10 ekim 2020) https://digitalcommons.pepperdine.edu/etd/644

Hiles, E. (2018). Parents' reasons for sending their child to Montessori schools. Journal of Montessori Research, 4(1), 1-13.

Ilgar, S. (2013). The perceptions and support of parents and guardians whose children attend Montessori programs. The Anthropologist, 16(1-2), 241-249. https://doi.org/10.1080/09720073.2013.11891352.

Irving, S. C. (2017). Montessori Parent Education: An Action Research Report. Retrieved from Sophia, the St. Catherine University repository website: https://sophia.stkate.edu/maed/208.

Kahn, D. (1990). Implementing montessori education. USA: Namta.

Keskin, T. (2017). Montessori ile çocuk eğitimi. İstanbul: Mavi Çatı yayınları.

Korkmaz, E. (2006). Montessori metodu. Ankara: Alg1 yayınlar1.

Laski, E. V., Jordan, J. R., Daoust, C., \& Murray, A. K. (2015). What makes mathematics manipulatives effective? Lessons from cognitive science and Montessori education. SAGE Open, 5(2), 1-8.http://dx.doi.org/10.1177/2158244015589588 
Lillard, A. S. (2012). Preschool children's development in classic Montessori, supplemented Montessori, and conventional programs. Journal of School Pyschology, 50, 379-401. doi:10.1016/j.jsp.2012.01.001

Lillard, A. S., \& McHugh, V. (2019). Authentic Montessori: The Dottoressa's View at the End of Her Life Part I. Journal of Montessori Research, 5(1), 1-18.

Lillard, A., \& Else-Quest, N. (2006). The early years: evaluating Montessori. Science, 313(5795), 1893-1894.

Lillard, P.P. \& Jessen, L. L. (2015). Doğumdan itibaren Montessori. İstanbul: Kaknüs yayınları.

Lillard, P.P. (2013). Montessori Modern Bir Yaklaşım. İstanbul: Kaknüs yayınları.

Merriam, S. B. (2018). Nitel araștırma desen ve uygulama için bir rehber. S. Turan (Çev. Ed.) (Üçüncü basımdan çeviri). Ankara: Nobel Yayın.

Mutlu, B., Ergişi, A., Ayhan, A. B., \& Aral, N. (2012). Okul öncesi dönemde Montessori eğitimi. Ankara Sağllk Bilimleri Dergisi, 1(3), 113-128.

Oğuz, B. U., \& Akyol, A. K. (2006). Çocuk eğitiminde Montessori yaklaşımı. C..Ü. Sosyal Bilimler Enstitïsü Dergisi, 243-256.

Öngören, S. (2008). Okulöncesi eğitim kurumlarna devam eden 4-5 yas grubu çocuklarna geometrik şekil kavram kazandırmada Montessori eğitim yönteminin etkililiüi. Yayınlanmamış yüksek lisans tezi, Selçuk Üniversitesi, Sosyal Bilimler Enstitüsü, Konya.

Özbek Ayaz, C. (2017). Eğitimde Tabula Rasa anlayışını yıkan ve çocuğun rönesansını yaratan bir devrim: Montessori Metodu. E. Aktan Acar (Ed.). Erken çocukluk eğ̈itimi moz̧aiği içinde (s. 320-346). Ankara: Nobel Yayın.

Parker, D. E. (2007). Navigating the social/cultural politics of school choice: "Why do parents choose Montessori?": A case study. The University of North Carolina at Greensboro.

Pickard, M. E. (2019). Parent education: the effects of educating montessori parents on thefirst plane of development in the kindergarten year in a mixed-age classroom. Retrieved from Sophia, the St. Catherine University repository website: https://sophia.stkate.edu/maed/334.

Schweinhart, L. J. (2017). Günümüzde erken çocukluk eğitimi ve müfredat modelleri. E. Aktan Acar (Ed.). Erken çocukluk eğitimi mozaiğ içinde (s. 1-11). Ankara: Nobel Yayın.

Stipek, D. J., \& Byler, P. (1997). Early childhood education teachers: Do they practice what they preach? Early Childhood Research Quarterly, 305-325.

Topbaş, E. (2013). Montessori yöntemiyle çocuk eğitimi. Ankara: Panama yayıncilık.

Toran, M. (2011). Montessori yönteminin çocuklarn kavram edinimi, sosyal uyumlar ve kü̧̈ük kas motor becerileri üzerindeki etkisinin incelenmesi. Yayımlanmamış doktora tezi, Gazi Üniversitesi, Eğitim Bilimleri Enstitüsü, Ankara.

Torrence, M. (2012). An idea whose time has come. Montessori Life, 24(2), 18-23. 
Ulutaş, D. D., \& Tutkun, A. G. (2015). Montessori eğitim yöntemi ve uygulama örnekleri. Okul Öncesi Eğitimde Alternatif Yaklaşımlar içinde (s. 43-72). Ankara: Hedef CS Basın Yayın.

Walls, J. K. (2018). To what extent do parents of montessori-educated children" do montessori" at home? preliminary findings and future directions. Journal of Montessori Research, 4(1), 14-24.

Yıldırım Doğru, S.S. (2009). Özel öğretimde kullanılan alternatif programlar Montessori yaklaşımı. TÜBAV Bilim Dergisi, 2(1), 107-116.

Yiğit, T. (2008). Okulöncesi eğitim kurumlarnda Montessori ve geleneksel öğretim yöntemleri alan çocuklarn sayı kavramın kazanma davranıslarmın karşılaştırlması. Yayımlanmamış yüksek lisans tezi, Selçuk Üniversitesi, Sosyal Bilimler Enstitüsü, Konya.

Yücesan, Y., \& Özyürek, A. (2017). Montessori eğitimi alan ve almayan okul öncesi dönem çocuklarının problem ve davranışlarının incelenmesi. LAÜ Sosyal Bilimler Dergisi, 8(2), 215226.

Zarybnisky, E. M. (2010). A ray of light: a mixed-methods approach to understanding why parents choose montessori education. ETD collection for University of Nebraska - Lincoln. Erişim linki: http://digitalcommons.unl.edu/dissertations/AAI3403514

Zigler, E., Walter, S., \& Gilliam, S. M. (2006). A vision for universal preschool education. Cambridge University Press. 